\title{
Faktor-Faktor yang berhubungan dengan Pencapaian Kepuasan Layanan Masa Nifas
}

\author{
Dewi Susilawati, Nur Fadjri Nilakesuma* \\ Prodi Kebidanan Program Sarjana dan Prodi Profei Bidan Program Profesi STIKes MERCUBAKTIJAYA Padang \\ *Correspondence email: nurfadjrink@gmail.com
}

\begin{abstract}
Abstrak. Salah satu alat ukur pelayanan kebidanan dikatakan berkualitas apabila suatu pelayanan kebidanan dapat memuaskan klien sesuai dengan tingkat kepuasan. Kepuasan klien dipengaruhi oleh faktor internal dan faktor ekternal. Faktor internal berasal dari klien sendiri (umur, pendidikan, jarak kehamilan, paritas dan pekerjaan) dan faktor ekternal seperti tindakan yang diberikan oleh tenaga kesehatan. Kepuasan klien bukan hanya menjadi tanggujawab manajemen atas tetapi sudah menjadi budaya dan komitmen seluruh karyawan. Semakin rendah mutu pelayanan kesehatan maka akan semakin rendah pula tingkat kepuasan pasien. Tujuan Penelitian adalah untuk mengetahui faktor - faktor yang berhubungan dengan pencapaian kepuasanan layanan masa nifas. Jenis penelitian ini adalah deskripsi analitik dengan rancangan Cross Sectional. Sampel penelitian ini adalah ibu nifas yang mendapatkan pelayanan mulai dari kehamilan sampai nifas oleh bidan di Bidan Praktik Mandiri (PMB) di Kabupaten Agam dan Pasaman. Teknik pengambilan sampel adalah dengan menggunakan accidental sampling dengan kurung waktu 1 bulan yaitu dari tanggal 1 Juli - 31 Juli 2020 yaitu sebanyak 69 ibu nifas. Data diolah dengan computer. Analisa data menggunakan uji ChiSquare.Hasil penelitian didapatkan faktor yang berhubungan dengan kepuasan layanan masa nifas adalah umur, tingkat pendidikan dan mutu layanan. Sementara untuk faktor paritas dan pekerjaan tidak ada hubungan dengan kepuasan layanan masa nifas. Kesimpulan penelitian ini adalah variabel yang berhubungan dengan kepuasan layanan masa nifas adalah umur, tingkat pendidikan dan mutu layanan sementara paritas dan pekerja tidak ada hubungan dengan tingkat kepuasan responden terhadap pelayanan yang di berikannya.
\end{abstract}

Kata kunci: Mutu Pelayanan; Faktor yang Berhubungan dengan Kepuasan; Kepuasan Pelayanan

Abstract. One of the measuring tools for midwifery services is said to be of quality if a midwifery service can satisfy the client according to the level of satisfaction. Client satisfaction is influenced by internal factors and external factors. Internal factors come from the client himself (age, education, pregnancy distance, parity, and occupation) and external factors such as actions given by health workers. Client satisfaction is not only the responsibility of top management but has become the culture and commitment of all employees. The lower the quality of health services, the lower the level of patient satisfaction. The purpose of the study was to determine the factors associated with the achievement of postpartum service satisfaction. This type of research is an analytic description with a cross-sectional design. The sample of this study was postpartum mothers who received services from pregnancy to childbirth by midwives at Independent Practice Midwives (PMB) in Agam and Pasaman Regencies. The sampling technique was using accidental sampling with a period of 1 month, namely from July 1 to July 31, 2020, as many as 69 postpartum mothers. The data is processed by computer. Analysis of the data using the Chi-Square test. The results showed that the factors associated with postpartum service satisfaction were age, education level and service quality. Meanwhile, for parity and work factors, there is no relationship with postpartum service satisfaction. This study concludes that the variables associated with postpartum service satisfaction are age, education level and service quality, while parity and workers have no relationship with the respondent's level of satisfaction with the services they provide.

Keywords: Factors Related to Satisfaction; Service Satisfaction; Service Quality

\section{PENDAHULUAN}

Masa nifas adalah masa yang paling penting di perhatika dalam menurun Angka Kematian Ibu (AKI) di Indonesia. Berbagai pengalaman dalam menanggulangi kematian ibu dan bayi dibanyak Negara, pakar kesehatan menganjurkan upaya penurunan AKI di fokuskan pada periode intrapartum. Upaya ini telah terbukti menyelamatkan lebih dari separuh ibu bersalin dan bayi baru lahir yang disertai dengan penyulit proses persalinan atau komplikasi yang mengancam jiwa (Saleha, 2014).

Survey penduduk antar sensus tahun 2015 AKI sebesar 305/100.000 kelahiran hidup. Berdasarkan Profil Kesehatan Provinsi Sumatera Barat tahun 2017, AKI di
Sumatera Barat adalah 107/100.000 kelahiran hidup (Kemenkes RI, 2018).

Jumlah kematian ibu di kabupaten Agam tahun 2018 adalah sebanyak 12 kasus kematian ibu dimana 6 kasus terjadi pada masa nifas (Tim Penyusun Data Perspektif Gender Kabupaten Agam, 2019). Semetara pada kabupaten pasaman angka kematian ibu tahun 2012 sebanyak 7 kasus dimana 2 kasus terjadi pada masa nifas dan 5 pada masa persalinan (Tim Penyusun Buku Data Profil Gender Kabupaten Pasaman, 2019). Komplikasi dan kematian ibu salah satunya disebabkan karena masih banyak bidan belum memberikan pelayanan yang optimal ke ibu selama masa kehamilan, persalinan, dan nifas. 
Strategi pemerintah dalam menurunkan AKI salah satunya adalah dengan menjamin setiap ibu mendapatkan pelayanan yang berkesinambungan (continuity of care) dimulai dari kehamilan, persalinan sampai nifas sehingga memberikan dampak besar bagi kesehatan ibu dan anak (Kemenkes RI, 2018).

Salah satu alat ukur pelayanan kebidanan dikatakan berkualitas apabila suatu pelayanan kebidanan dapat memuaskan klien sesuai dengan tingkat kepuasan. Pelayanan yang diberikan harus sesuai dengan kode etik dan standar pelayanan kebidanan yang telah ditetapkan (Fauziah, Maffuah and Nuswantaro, 2018).

Kepuasan klien dipengaruhi oleh faktor internal dan faktor ekternal. Faktor internal berasal dari klien sendiri (umur, pendidikan, jarak kehamilan, paritas dan pekerjaan) dan faktor ekternal seperti tindakan yang diberikan oleh tenaga kesehatan (Agustina, 2015; Fauziah, Maffuah and Nuswantaro, 2018; Iryadi, Prihartini and Irmawati, 2019).

Kepuasan klien bukan hanya menjadi tanggujawab manajemen atas tetapi sudah menjadi budaya dan komitmen seluruh karyawan. Semakin rendah mutu pelayanan kesehatan maka akan semakin rendah pula tingkat kepuasan pasien (Iryadi, Prihartini and Irmawati, 2019).

Kepuasan atau ketidakpuasan yang dirasakan oleh pasien akan mempengaruhi pemikiran pasien dalam menggunakan jasa pelayanan dimasa yang akan datang. Apabila ibu nifas merasa puas terhadap pelayanan yang diberikan oleh tenaga kesehatan maka akan mempengaruhi pemikiran ibu dalam menggunakan jasa pelayanan kebidanan (Agustina, 2015).

\section{METODE}

Jenis penelitian ini adalah deskripsi analitik dengan rancangan Cross Sectional. Sampel penelitian ini adalah ibu nifas yang mendapatkan pelayanan mulai dari kehamilan sampai nifas oleh bidan di Bidan Praktik Mandiri (PMB) di Kabupaten Agam dan Pasaman. Teknik pengambilan sampel adalah dengan menggunakan accidental sampling dengan kurung waktu 1 bulan yaitu dari tanggal 1 Juli - 31 Juli 2020 yaitu sebanyak 69 ibu nifas

Variabel independen penelitian ini adalah demografi ibu (Umur, paritas, pendidikan, pekerjaan) dan mutu pelayanan yang diberikan. Sedangkan variable dependennya adalah tingkat kepuasan responden. Pengolahan data dengan cara editing, coding, entry, tabulating, dan cleaning. Analisa data menggunakan uji Chi-Square dengan apilikasi computer pada variabel mutu pelayanan, kualitas hidup ibu nifas dan kualitas hidup ibu nifas .

\section{HASIL DAN PEMBAHASAN \\ Analisa Univariat}

Tabel 1. Distribusi Frekuensi Faktor yang Berhubungan dengan Pencapain Kepuasan Layanan Masa Nifas

\begin{tabular}{lcc}
\hline \multicolumn{1}{c}{ Variabel } & Frekuensi & Persentase \\
\hline Umur & 49 & 71 \\
Tidak Beresiko & 20 & 29 \\
Beresiko & & \\
Paritas & 37 & 53,6 \\
Tidak Beresiko & 32 & 46,4 \\
Beresiko & & \\
Tingkat Pendidikan & 43 & 62,3 \\
Tinggi & 26 & 37,7 \\
Rendah & & \\
Pekerjaan & 58 & 84,1 \\
Tidak Bekerja & 11 & 15,9 \\
Bekerja & & \\
Mutu Pelayanan & 40 & 58 \\
Baik & 17 & 24,6 \\
Cukup & 12 & 17,4 \\
Kurang & & \\
Kepuasan Layanan & 41 & 59,4 \\
Tinggi & 24 & 34,8 \\
Sedang & 4 & 5,8 \\
Rendah & & \\
\hline
\end{tabular}

Hasil penelitian mengenai karakteristik internal responden (umur, paritas, tingkat pendidikan, dan pekerjaan) didapatkan sebagian besar umur dan paritas responden terkategori tidak beresiko. Sebagian besar tingkat pendidikan responden terkategori tinggi. Tingkat pendidikan merupakan salah satu faktor yang mendukung kemampuan seseorang untuk menerima informasi. Tingkat pendidikan seseorang mempengaruhi proses belajar. Mayoritas responden tidak bekerja. Pekerjaan dan jenis pekerjaan seseorang sangat berhubungan dengan pergaulan sosial sehingga sangat memungkinkan bagi individu untuk berinteraksi dan memperoleh informasi yang luas. Pola pikir responden dalam memberikan penilaian atas pelayanan asuhan masa nifas yang diterimanya berdasarkan perbandingan antara persepsi dengan informasi yang diperoleh (Fauziah, Marfuah and Nuswantoro, 2018).

\section{Analisa Bivariat Umur}

Tabel 2. Hubungan Umur Dengan Pencapian Kepuasan Layanan Masa Nifas

\begin{tabular}{|c|c|c|c|c|c|c|c|c|c|}
\hline \multirow{3}{*}{ Umur } & \multicolumn{6}{|c|}{ Kepuasan Layanan } & \multicolumn{2}{|c|}{ Total } & \multirow[t]{3}{*}{$P$ value } \\
\hline & \multicolumn{2}{|c|}{ Tinggi } & \multicolumn{2}{|c|}{ Sedang } & \multicolumn{2}{|c|}{ Rendah } & & & \\
\hline & f & $\%$ & f & $\%$ & f & $\%$ & f & $\%$ & \\
\hline Tidak Beresiko & 33 & 67,3 & 15 & 30,6 & 1 & 2 & 49 & 100 & 0,034 \\
\hline Beresiko & 8 & 40 & 9 & 45 & 3 & 15 & 20 & 100 & \\
\hline Total & 41 & 59,4 & 24 & 34,8 & 4 & 5,8 & 69 & 100 & \\
\hline
\end{tabular}

Berdasarkan tabel 2 didapatkan sebagian besar reponden yang berumur tidak beresiko memiliki tingkat kepuasan yang tinggi terhadap pelayanan nifas yang diberikan oleh petugas dan juga terdapat hubungan antara umur dengan kepuasan pelayanan. Kepuasan konsumen adalah perasaan senang atau kecewa 
seseorang yang muncul setelah membandingkan kinerja yang dipikirkan terhadap kinerja yang diharapkan. Umur memiliki hubungan dengan tingkat kematangan dan kepekaan seseorang dalam berpikir. Semakin bertambah umur seseorang maka bertambah pula kemampuan terhadap pemikiran dan daya tanggapnya, oleh karena itu bertambah banyak juga wawasan yang diperolehnya. umur yang menyebabkan pemikiran dan daya tanggap seseorang untuk berkembang.

Hasil penelitian juga menyebutkan bahwa umur tidak beresiko merupakan umur yang aman untuk kehamilan, persalinan, serta kematian ibu akan meningkat pada umur beresiko, dan pada umur tidak beresiko memiliki emosi stabil, lebih berfikir secara rasional, pengetahuan ibu semakin baik dalam mencari informasi dan lebih menyadari tentang pentingnya menjaga kesehatan mereka sehingga mampu menganalisa apakah puas dengan pelayanan nifas yang diberikan (Aulia, 2021)

Tabel 3. Hubungan Paritas Dengan Pencapian Kepuasan Layanan Masa Nifas

\begin{tabular}{|c|c|c|c|c|c|c|c|c|c|}
\hline \multirow{3}{*}{ Paritas } & \multicolumn{6}{|c|}{ Kepuasan Layanan } & \multirow{2}{*}{\multicolumn{2}{|c|}{ Total }} & \multirow[t]{3}{*}{ P value } \\
\hline & \multicolumn{2}{|c|}{ Tinggi } & \multicolumn{2}{|c|}{ Sedang } & \multicolumn{2}{|c|}{ Rendah } & & & \\
\hline & f & $\%$ & f & $\%$ & f & $\%$ & f & $\%$ & \\
\hline Tidak Beresiko & 23 & 62.2 & 14 & 37,8 & 0 & 0 & 37 & 100 & 0,085 \\
\hline Beresiko & 18 & 56,2 & 24 & 34,8 & 4 & 12,5 & 32 & 100 & \\
\hline Total & 41 & 59,4 & 24 & 34,8 & 4 & 5,8 & 69 & 100 & \\
\hline
\end{tabular}

Pada tabel 3 didapatkan pada paritas tidak beresiko memiliki tingkat kepuasan tinggi terhadap pelayanan masa nifas, dan berdasarkan hasil uji chi square tidak ada hubungan antara Paritas Dengan Pencapian Kepuasan Layanan Masa Nifas.

Ditinjau dari sisi pengalaman, paritas adalah yang membentuk pengalaman ibu dalam menjalani kehamilan. Bagi ibu primipara/ tidak beresiko lebih tertarik untuk kontak kenakes pasca bersalin untuk menanyakan proses pemulihan padadirinya. Sebaliknya ibu multipara/ beresiko tidak tertarik berkunjung kepelayanan atau tenaga medis pasca bersalin karena berpendapat telah pengalaman kemudian akhirnya merasa malas untuk kontak nifas ketenaga medis. Kurangnya kunjungan ibu multipara selama masa nifas tetntu akan mempengaruhi terhadap kepuasan pelayanan yang didapatkan. Bagaimana akan merasa puas jika ibu nifas beresiko tidak pernah melakukan kunjungan (Pradani and Kurniasari, 2018).

Tabel 4. Hubungan Tingkat Pendidikan Dengan Pencapian Kepuasan Layanan Masa Nifas

\begin{tabular}{|c|c|c|c|c|c|c|c|c|c|}
\hline \multirow{3}{*}{$\begin{array}{c}\text { Tingkat } \\
\text { Pendidikan }\end{array}$} & \multicolumn{6}{|c|}{ Kepuasan Layanan } & \multirow{2}{*}{\multicolumn{2}{|c|}{ Total }} & \multirow[t]{3}{*}{ P value } \\
\hline & \multicolumn{2}{|c|}{ Tinggi } & \multicolumn{2}{|c|}{ Sedang } & \multicolumn{2}{|c|}{ Rendah } & & & \\
\hline & f & $\%$ & f & $\%$ & f & $\%$ & f & $\%$ & \\
\hline Tinggi & 30 & 69,8 & 12 & 27,9 & 1 & 2,3 & 43 & 100 & 0,050 \\
\hline Rendah & 11 & 42,3 & 12 & 46,2 & 3 & 11,5 & 26 & 100 & \\
\hline Total & 41 & 59,4 & 24 & 34,8 & 4 & 5,8 & 69 & 100 & \\
\hline
\end{tabular}

Kepuasan pelayanan yang diterima pada masa nifas memiliki hubungan dengan tingkat pendidikan responden berdasarkan hasil uji Chi - square. Berdasarkan table 4 didapatkan, responden dengan tingkat pendidikan tinggi memiliki kepuasan yang tinggi terhadap pelayanan masa nifas yang diterima nya. Tingkat pendidikan yang tinggi mengakibatkan peningkatan kemampuan responden untuk meningkatkan pengetahuanya dan memberikan responden untuk menganaliasa semua pelayanan masa nifas yang diberikan, sehingga memunculkan perasaan senang setelah membandingkan kinerja yang terpikir oleh mereka dengan kinerja yang diharapkan. Ketidaktahuan dapat disebabkan karena pendidikan yang rendah, seseorang dengan tingkat pendidikan yang terlalu rendah akan sulit mencerna dan menerima pesan,serta informasi yang disampaikan (Pradani and Kurniasari, 2018)

Tabel 5. Hubungan Pekerjaan Dengan Pencapian Kepuasan Layanan Masa Nifas

\begin{tabular}{|c|c|c|c|c|c|c|c|c|c|}
\hline \multirow[t]{3}{*}{ Pekerjaan } & \multicolumn{6}{|c|}{ Kepuasan Layanan } & \multicolumn{2}{|c|}{ Total } & \multirow[t]{3}{*}{ P value } \\
\hline & \multicolumn{2}{|c|}{ Tinggi } & \multicolumn{2}{|c|}{ Sedang } & \multicolumn{2}{|c|}{ Rendah } & & & \\
\hline & f & $\%$ & f & $\%$ & f & $\%$ & f & $\%$ & \\
\hline Tidak Bekerja & 36 & 62,1 & 19 & 32,8 & 3 & 5,2 & 58 & 100 & 0,576 \\
\hline Bekerja & 5 & 45,5 & 5 & 45,5 & 1 & 9,1 & 11 & 100 & \\
\hline Total & 52 & 75,4 & 17 & 24,6 & & & 69 & 100 & \\
\hline
\end{tabular}

Berdasarkan hasil uji Chi - Square terhadap pekerjaan dengan kepuasan pelayanan masa nifas didapatkan tidak ada hubungan dengan nilai $\mathrm{P}$ value $>0$. 05. Pada table 5 didapatkan ibu yang bekerja memiliki kepuasan yang tinggi terhadap pelayanan masa nifas. Hal ini didasari oleh konsep pekerjaan dan jenis pekerjaan seseorang sangat berhubungan dengan pergaulan sosial sehingga sangat memungkinkan bagi individu untuk berinteraksi dan memperoleh informasi yang luas. Semakin ibu berinteraksi dengan orang lain akan menambah pengetahuan ibu terhadap sesuatu permasalahan. Akan tetapi keadaan ini memilki arti negative jika responden percaya begitu saja terhadap solusi/ materi yang didiskusikan. Karena bisa saja apa yang didiskusikan belum tentu benar semua. Ibu yang bekerja memiliki waktu yang terbatas untuk melakukan kunjungan ibu nifas sehingga hal ini mempengaruhi perasaan dan persepsi mereka terhadap pelayanan masa nifas yang akan dan telah diterimanya nanti

Tabel 6. Hubungan Mutu Pelayanan Dengan Pencapian Kepuasan Layanan Masa Nifas

\begin{tabular}{|c|c|c|c|c|c|c|c|c|c|}
\hline \multirow{3}{*}{$\begin{array}{c}\text { Mutu } \\
\text { Pelayanan }\end{array}$} & \multicolumn{6}{|c|}{ Kepuasan Layanan } & \multirow{2}{*}{\multicolumn{2}{|c|}{ Total }} & \multirow[t]{3}{*}{ P value } \\
\hline & \multicolumn{2}{|c|}{ Tinggi } & \multicolumn{2}{|c|}{ Sedang } & \multicolumn{2}{|c|}{ Rendah } & & & \\
\hline & f & $\%$ & f & $\%$ & f & $\%$ & $\mathbf{f}$ & $\%$ & \\
\hline Baik & 35 & 87,5 & 5 & 12 & 0 & 0 & 40 & 100 & 0,000 \\
\hline Cukup & 6 & 35,3 & 11 & 64,7 & 0 & 0 & 17 & 100 & \\
\hline Kurang & 0 & 0 & 8 & 66,7 & 4 & 5,8 & 12 & 100 & \\
\hline Total & 41 & 59,4 & 24 & 34,8 & 4 & 5,8 & 69 & 100 & \\
\hline
\end{tabular}

Berdasarkan tabel 6 didapatkan mutu layanan baik yang didapatkan oleh responden memiliki kepuasan yang tinggi terhadap pelayanan masa nifas. Hasil uji Chi - Square didapatkan Pvalue < 0.05 yang berarti ada hubungan antara mutu layanan dengan kepuasanan 
layanan masa nifas. Kepuasan masa nifas adalah perasaan konsumen dalam hal ini ibu nifas setelah membandingkan hasil yang diperoleh dengan harapan yang dimiliki, dimana hasil yang diharapkan sesuai maka ibu nifas akan puas.

Ibu nifas yang puas adalah ibu nifas yang merasa mendapat value dari pemasok, produsen atau penyedia jasa. Value ini berasal dari produk, pelayanan,system atau sesuatu yang bersifat emosi. Kalau pelanggan mengatakan bahwa value adalah produk yang berkualitas, maka kepuasan terjadi kalau pelanggan mendapatkan produk yang berkualitas. Kalau value bagi pelanggan adalah kenyamanan, maka kepuasan akan datang apabila pelayanan yang diperoleh benar-benar nyaman. Kalau value dari pelanggan adalah harga murah, maka pelanggan akan puas kepada produsen yang memberikan harga yang paling kompetitif.

Kepuasan pelanggan adalah hasil akumulasi dari konsumen atau pelanggan dalam menggunakan produk dan jasa. Oleh karena itu, setiap transaksi atau pengalaman baru,akan memberikan pengaruh terhadap kepuasan pelanggan. Kepuasan pasien terhadap pelayanan nifas yang dilaksanakan oleh bidan merupakan salah satu indikator untuk mengukur mutu pelayanan kesehatan. Pasien akan selalu mencari pelayanan kesehatan difasilitas yang kinerja pelayanan kesehatannya dapat memenuhi harapan pasien. Suatu pelayanan dinilai memuaskan bila pelayanan tersebut dapat memenuhi kebutuhan dan harapan klien (Aminah, 2018). Semakin rendah mutu pelayanan kesehatan maka akan semakin rendah pula tingkat kepuasan pasien. (Iryadi, Prihartini and Irmawati, 2019).

\section{SIMPULAN}

Kesimpulan penelitian ini adalah variabel yang berhubungan dengan kepuasan layanan masa nifas adalah umur, tingkat pendidikan dan mutu layanan sementara paritas dan pekerja tidak ada hubungan dengan tingkat kepuasan responden terhadap pelayanan yang di berikannya.

\section{DAFTAR PUSTAKA}

Agustina, S. (2015) 'Hubungan Antara Pengetahuan, Sikap dan Pendidikan Ibu Nifas terhadap Kepuasan Ibu terhadap Pelaksanaan IMD', Jurnal Bidan Ilmu Kesehatan, 5(1), pp. 205-210.

Aminah, A. (2018) 'Hubungan Pelaksanaan Program dan Kebijakan Teknis Pelayanan oleh Bidan Desa dengan Kepuasan Ibu Nifas di Wilayah Kerja Puskesmas Tanah Jawa', Jurnal Ilmiah Kebidanan Imelda, 3(1), pp. 233-239. Available at: https://core.ac.uk/download/pdf/288016739.pdf.

Aulia, A. R. (2021) 'IBU NIFAS DI WILAYAH KERJA PUSKESMAS SAMATA KABUPATEN GOWA TAHUN 2019-2020', repository UNHAS, MAkasar. Available at: http://repository.unhas.ac.id/id/eprint/4543/2/K01 1171003_skripsi 1-2.pdf.

Fauziah, N., Maffuah, D. and Nuswantaro, B. (2018) 'Pencapaian Kepuasan Pasien terhadap Pelayanan Kebidanan Ibu Nifas di RSUD Surakarta', Nurnal Menara Medika, 1(1), pp. 41-48.

Iryadi, R., Prihartini, A. R. and Irmawati, S. (2019) 'Hubungan Mutu Pelayanan Kebidanan dengan Kepuasan Pasien di Ruang Rawat Inap Kebidanan', Jurnal Kesehatan Pertiwi, 1(2), pp. $48-52$.

Kemenkes RI (2018) Data Dan Informasi Profil Kesehtan Indonesia 2017, Kementrian Kesehatan Republik Indonesia.

Pradani, N. N. W. and Kurniasari, C. V. (2018) 'Hubungan Paritas, Umur Dan Pendidikan Dengan Kunjungan Nifas', OKSITOSIN: Jurnal Ilmiah Kebidanan, 5(2), pp. 67-78. doi: 10.35316/oksitosin.v5i2.346.

Saleha. (2014). Asuhan Kebidanan Masa Nifas. Jakarta: Salemba Medika.

Tim Penyusun Buku Data Profil Gender Kabupaten Pasaman (2019) Data Perspektif Gender Kabupaten Pasaman Tahun 2019, Dinas Pemberdayaan Perempuan dan Perlindungan Anak Kabupaten Pasaman. 